Jurnal Ilmiah SEMANTIKA

Volume 2, No. 02, Februari 2021 p. 41-51

\title{
Senyapan Tuturan Presiden Joko Widodo Dalam Wawancara Eksklusif di Kompas TV
}

\author{
The speech of President Joko Widodo in an Exclusive Interview on Kompas TV \\ Dian Etikasari*1, Elen Nurjanah ${ }^{2}$, Rahmawati Mulyaningtyas ${ }^{3}$ \\ 1,2,3 Jurusan Tadris Bahasa Indonesia, Fakultas Tarbiyah dan Ilmu Keguruan, IAIN Tulungagung, \\ Indonesia \\ e-mail: *1etikadian@gmail.com, ${ }^{2}$ elennurjanah3@gmail.com, ${ }^{3}$ rahmawatimulyaningtyas@gmail.com
}

\begin{abstract}
ABSTRAK
Presiden Joko Widodo sebagai orang nomor satu di Republik Indonesia selalu mendapatkan banyak sorotan publik, baik dalam kehidupan pribadi maupun profesinya. Dengan adanya UU Cipta Kerja dan kasus Covid-19 di Indonesia, Presiden mendapatkan banyak kritikan. Hal ini menyebabkan salah satu media mengadakan wawancara khusus dengan Presiden Joko Widodo. Selama wawancara berlangsung, terjadi senyapan saat beliau berbicara. Senyapan dilakukan Presiden Joko Widodo saat beberapa kali menjawab pertanyaan dari pewawancara. Senyapan dalam tuturan penting untuk diteliti karena dapat mengungkapkan proses mental penutur. Selain itu, senyapan membutuhkan pembahasan lebih dalam untuk menambah informasi tentang produksi ujaran pada bidang ilmu psikolinguistik. Penelitian ini bertujuan untuk mendeskripsikan tentang bentuk senyapan dan penyebabnya dalam wawancara. Penelitian ini menggunakan rancangan deskriptif kualitatif. Sumber data penelitian ini berupa produksi ujaran Presiden Joko Widodo yang diwawancarai secara eksklusif di Kompas TV pada Senin, 16 November 2020. Hasil penelitian ini, pertama bentuk senyapan meliputi senyapan terisi, senyapan pengulangan, senyapan pemanjangan, senyapan kombinasi, senyapan false start, dan senyapan diam. Kedua, penyebab senyapan meliputi terlanjur memulai ujaran, tetapi sebenarnya belum siap untuk keseluruhan kalimat itu; lupa akan kata-kata yang diperlukan; kehati-hatian memilih kata; ketidaksiapan memulai tuturan; adanya kekeliruan tuturan; pengubahan isi tuturan; ragu-ragu karena mengingat kejadian di masa lampau; mencari katakata yang tepat untuk disampaikan.
\end{abstract}

Kata kunci: senyapan, tuturan, Presiden Joko Widodo, wawancara

\begin{abstract}
President Joko Widodo as the number one person in Republic of Indonesia has always brought him into a lot of public spotlight, both in his personal life and in his profession. By the existence of the Job Creation Law and the Covid-19 cases in Indonesia, the President has received a lot of criticism. This caused one of the mass media to hold a special interview with President Joko Widodo. During the interview, there were silences when he was speaking. President Joko Widodo was silent several times while answering the interviewer's questions. Silence in speech is significant to learn because it can reveal the speaker's mental processes. In addition, silence requires a deeper discussion to add information about speech production in the psycholinguistic field. This study aims to describe the form of silence and its causes in interviews. This study used a qualitative descriptive design. The data source of this research is the production of a speech by President Joko Widodo who was interviewed exclusively on Kompas TV on Monday, November 16, 2020. The results of this study, first, the form of silence includes filled silences, repetition silences, extended silences, combination silences, false start silences, and quiet silences. Second, the causes of silence include already starting the utterance, but actually not being ready for the whole sentence; forgetting the necessary words; careful choice of words; unpreparedness to start speech; an error in speech; changing the content of the speech; hesitation because of remembering events in the past; trying to find the right words to say. Keywords: silence, speech, President Joko Widodo, interview.
\end{abstract}




\section{PENDAHULUAN}

Presiden Joko Widodo merupakan kepala negara sekaligus kepala pemerintahan di Negara Kesatuan Republik Indonesia. Presiden Joko Widodo sebagai orang nomor satu di Republik Indonesia selalu mendapatkan banyak sorotan publik, baik dalam kehidupan pribadi maupun profesinya. Hal utama yang paling mendapatkan sorotan adalah kebijakan dan program kerjanya. Apalagi dengan adanya UU Cipta Kerja yang disahkan oleh DPR RI pada 5 Oktober 2020 lalu dan masalah penanganan kasus Covid-19 di Indonesia, Presiden Joko Widodo mendapatkan banyak kritikan. Hal ini menyebabkan beberapa media berusaha untuk menggali lebih dalam tanggapan presiden mengenai kedua isu tersebut. Salah satu media yang mengadakan wawancara khusus dengan Presiden Joko Widodo adalah Kompas TV. Melalui salah satu acara bertajuk Rosi Spesial, Presiden Joko Widodo diwawancarai secara eksklusif oleh Rosianna Silalahi, seorang jurnalis senior Kompas TV.

Selama wawancara berlangsung, Presiden Joko Widodo menjawab segala pertanyaan dan menanggapi pernyataan Rosianna Silalahi. Namun, terjadi senyapan saat beliau berbicara. Senyapan dilakukan Presiden Joko Widodo saat beberapa kali menjawab pertanyaan dari pewawancara. Senyapan terjadi saat Presiden Joko Widodo terdiam, agak ragu, terdapat banyak jeda, dan melakukan pengulangan bicara saat menjawab pertanyaan dalam wawancara. Hal ini sesuai bahwa seorang penutur sering kali mengalami hambatan dalam berbicara berupa interupsi diam, pengucapan bunyi, kata, maupun kalimat yang bukan menjadi bagian dari pesan, mengulang kata, dan tuturannya terkesan kurang lancar dan ideal[1]. Kemudian tuturan dalam wawancara adalah tuturan berbentuk spontan[2]. Hal yang mencirikan tuturan spontan adalah diisi jeda, pengulangan, perbaikan, dan kesalahan di awal tuturan.

Senyapan dapat terjadi pada setiap penutur dan dalam berbagai situasi, baik situasi formal maupun nonformal[3]. Senyapan yang terjadi pada tuturan dapat dilakukan penutur dengan sengaja maupun sebaliknya. Umumnya, kasus senyapan cenderung terjadi karena faktor ketidaksengajaan. Hal ini sesuai bahwa senyapan dan kilir lidah bisa terjadi karena disengaja maupun tidak. Namun, hal yang sering terjadi senyapan karena faktor tidak sengaja[4]. Senyapan dalam tuturan penting untuk diteliti karena dapat mengungkapkan proses mental penutur. Selain itu, senyapan membutuhkan pembahasan lebih dalam untuk menambah informasi tentang produksi ujaran pada bidang ilmu psikolinguistik. Fenomena senyapan penting untuk dikaji karena dapat menambah informasi tentang disiplin ilmupsikolinguistik[5]. Dalam memproduksi ujaran, seorang penutur biasanya berusaha untuk menyampaikan ujarannya secara ideal. Namun, pada praktiknya produksi ujaran tidak selalu lancar dan ideal karena aspek yang terlibat dalam produksi ujaran[6]. Produksi ujaran dipengaruhi oleh berbagai aspek. Oleh sebab itu, penutur tidak selalu lancar dalam memproduksi ujaran. Terkadang, seorang penutur harus berhenti sejenak untuk mencari dan menemukan satuan kebahasaan yang tepat atau penutur tidak berkonsentrasi sehingga ujarannya tidak sesuai dengan hal yang dimaksudkan. Senyapan merupakan salah satu masalah yang dianggap sepele. Padahal, senyapan cenderung mengganggu dan menghambat pesan penuturnya. Selain itu, adanya senyapan dan kilir lidah menunjukkan bahwa terdapat hambatan kognitif dalam perencanaan ujaran[7].

Penelitian mengenai senyapan dalam ujaran dengan judul Senyapan dan Penyebabnya pada Debat Final Pemilihan Kepala Daerah Khusus Ibu Kota Jakarta Tahun 2017 pernah dilakukan. Penelitian itu menghasilkan temuan (1) jenis senyapan pada debat, (2) distribusi senyapan, dan (3) faktor penyebab senyapan berbicara (2019)[8]. Selain itu, penelitian berjudul Senyapan di dalam Gelar Wicara The Tonight Show Starring Jimmy Fallon Suatu Analisis Psikolingusitik oleh peneliti [9] dimana penelitian tersebut bertujuan untuk mendeskripsikan (1) jenis senyapan dalam tuturan yang diteliti, dan (2) faktor penyebab senyapan dari tuturan yang diteliti (2020). Perbedaan kedua penelitian tersebut dengan penelitian ini adalah pada subjek penelitian. Penelitian ini menggunakan subjek penelitian orang nomor satu di Republik Indonesia yaitu Presiden Joko Widodo saat wawancara eksklusif dengan Kompas TV. Penelitian tentang senyapan dalam tuturan kepala negara cenderung masih jarang dilakukan.

Berdasarkan uraian di atas, penelitian ini mengkaji tentang senyapan dalam tuturan Presiden Joko Widodo selama wawancara eksklusif yang disiarkan Kompas TV. Penelitian ini bertujuan 
untuk (1) mendeskripsikan bentuk senyapan yang dilakukan Presiden Joko Widodo selama wawancara berlangsung dan (2) mendeskripsikan penyebab senyapan yang dilakukan Presiden Joko Widodo selama menjawab dan menanggapi pertanyaan dari pewawancara

\section{METODOLOGI PENELITIAN}

Penelitian ini menggunakan rancangan deskriptif kualitatif. Penelitian ini termasuk dalam kajian psikolinguistik. Sumber data penelitian ini berupa produksi ujaran Presiden Joko Widodo yang diwawancarai secara eksklusif di Kompas TV pada Senin, 16 November 2020. Data dalam penelitian ini adalah tuturan Presiden Joko Widodo berupa klausa, kalimat, maupun tuturan penuh yang mengandung senyapan. Teknik pengumpulan data yang digunakan dalam penelitian ini adalah dokumentasi berupa rekaman video wawancara.

Penelitian ini melalui beberapa tahapan antara lain peneliti mengumpulkan data, mereduksi data, menganalisis data, dan menyajikan hasil analisis data. Pengumpulan data dilakukan dengan cara mengunduh video rekaman wawancara eksklusif Presiden Joko Widodo di Kompas TV pada saluran YouTube. Lalu, peneliti mentranskrip hasil wawancara secara ortografis dengan mendengarkan video berulang-ulang untuk memastikan validitas transkripsi. Selanjutnya, transkripsi ditandai dengan keterangan letak senyapan (secara manual).

\section{HASIL DAN PEMBAHASAN}

\section{Hasil Penelitian}

Hasi penelitian ini meliputi dua hal, yaitu (1) deskripsi bentuk senyapan tuturan Presiden Joko Widodo dalam wawancara eksklusif di Kompas TV dan (2) deskripsi penyebab senyapan yang dilakukan Presiden Joko Widodo selama menjawab pertanyaan dari pewawancara dalam wawancara eksklusif di Kompas TV.

\section{Bentuk Senyapan dalam Tuturan Presiden Joko Widodo dalam Wawancara Ekslusif Kompas TV}

\section{Senyapan Terisi Berupa Bunyi}

Peneliti dalam mengidentifikasi data menemukan bentuk senyapan dari ujaran Presiden Joko Widodo, salah satunya senyapan terisi berupa bunyi. Senyapan tersebut muncul ketika presiden memberikan tanggapan terkait dengan penolakan Undang-Undang Cipta Kerja pada segmen pertama. Pada data 1 ini dapat dilihat senyapan terisi berupa bunyi ditandai dengan kemunculan bunyi e dan e... pada ujaran yang disampaikan oleh presiden. Hal tersebut dapat dilihat pada penggalan ujaran presiden pada data 1 .

(1) ... ada yang pro ada yang kontra itu biasa kok dan e saya melihat banyak yang belum memahami juga banyak yang belum membaca isi dari omnimbuslaw ini. Ini segini lo bukunya (menunjukkan perkiraan ketebalan Undang-Undang), jadi e... kalau sudah membaca ...

Selanjutnya pada segmen pertama ini juga ditemukan kembali senyapan terisi berupa bunyi ketika Presiden Joko Widodo memberikan tanggapan atas penyataan yang disampaikan oleh Rosi dalam acara tersebut. Rosi menyatakan bahwa terdapat banyak penolakan dari berbagai pihak karena menganggap terdapat pasal-pasal dalam Undang-Undang Cipta Kerja yang merugikan dan presiden dianggap tidak mementingkan rakyat kecil. Presiden menjelaskan bahwa dalam penyusunan Undang-Undang telah berdikusi dengan berbagai kalangan, di antaranya $\mathrm{Nu}$, Muhamadiyah, dan MUI. Dalam menyampaikan tuturannya tersebut ditemukan senyapan terisi berupa bunyi, yaitu bunyi e dan e.... Untuk senyapan e... muncul dua kali dalam tuturan presiden. Hal tersebut dapat dilihat pada data (2).

(2) kemudian juga sudah bertemu setelah e... proses omnimbuslaw ini dengan e NU sudah, dengan muhammadiyah sudah, dengan MUI sudah, dan saya mengucapkan terima kasih, 
banyak masukan-masukan dari beliau-beliau kepada kita, saya pak e... nanti bisa kita pakai sekali lagi dalam PP maupun Perpres dan ada kesamaan mengenai pemberdayaan UMKM, mengenai pembenahan ekonomi umat.

Kemudian pada segmen kedua memasuki pembahasan Covid-19 yang menjadi wabah nasional di Indonesia, presiden dalam memproduksi ujarannya ditemukan senyapan terisi berupa bunyi m.... Yang muncul setelah konstituen pertama. Senyapan tersebut muncul ketika presiden memberikan penegasan bahwa dalam penggunaan vaksin tidak boleh tergesa-gesa karena harus sesuai standart WHO. Senyapan tersebut dapat dilihat pada data (3).

(3) Kita tidak mau tergesa-gesa, kita mmm harus melalui tahapan-tahapan sesuai standar WHO, sesuai kaidah-kaidah scientific, harus itu.

\section{Senyapan Terisi Berupa Kata}

Dalam wawancara eksklusif Presiden Joko Widodo bersama Rosi di Kompas TV terdapat tiga segmen, yaitu segmen pertama pembahasan Undang-Undang Cipta Kerja, kedua tentang wabah covid-19, dan ketiga Pilkada. Pada segmen pertama pembahasan Undang-Undang Cipta Kerja dalam tuturan presiden ditemukan senyapan terisi berupa kata. Peneliti menyajikan contoh-contoh tuturan presiden yang termasuk dalam senyapan terisi berupa kata.

(4) ... perlu didengar iya, tapi apa ini undang-undang ini disiapkan dalam jangka yang sudah lama. Kemudian dibahas di DPR seingat saya delapan bulan dan juga sebuah proses yang lama di situ ada pro dan kontra, ada proses-proses apa demokrasi ...

(5) Sebelas kluster itu coba bayangkan, ada sebelas kluster urusan penyederhanaan perizinan, kemudian urusan investasi, kemudian urusan ketenagakerjaan, urusan pengadaan lahan, urusan kemudahan berusaha, urusan riset dan inovasi, urusan administrasi pemerintahan, urusan pengenaan sangsi, urusan UMKM, urusan kawasan ekonomi, urusan proyek pemerintah buanyak sekali yang di apa digarap dalam undang-undang cipta kerja ini.

Pada data 4 dan data 5 merupakan tanggapan Presiden Joko Widodo terkait Undang- Undan Cipta Kerja yang menimbulkan penolakan dari berbagai kalangan. Dalam tuturan tersebut presiden menjelaskan bahwa semua aspirasi masyarakat terkait dengan Undang- Undang akan didengar dan diterima. Dalam menyampaikan jawabannya atas pertanyaan Rosi dapat dilihat pada data 4 yang kemudian ditemukan senyapan terisi berupa kata yang ditandai dengan apa, pada kalimat tapi apa ini. Selanjutnya senyapan terisi berupa kata juga ditemukan pada tuturan selanjutnya yang disajikan pada data 5. Pada data tersebut terlihat bahwa senyapan terisi berupa kata ditandai dengan kata apa. Senyapan tersebut muncul ketika presiden memberikan jawaban terkait pertanyaan Rosi tentang kepercayaan masyarakat terhadap produk Undang-Undang Cipta Kerja.

Pada segmen ketiga pembahasan tentang Pilkada senyapan terisi berupa kata dalam tuturan presiden ditemukan kembali oleh peneliti. Senyapan terisi berupa kata muncul pada batas antara konstituen dengan konstituen dalam ujaran presiden yang ditandai dengan munculnya kata apa. Munculnya senyapan tersebut karena presiden berpikir konstituen yang sesuai dengan konstituen sebelumnya. Hal tersebut dapat dilihat pada data (6)

(6) ... enggak, saya kira dua-duanya sama. Tidak bisa kita apa.. tetep kesehatan nomor satu tetapi ekonomi juga harus berjalan politikpun juga jalan, yang paling penting sekali lagi bagaimana protokol kesehatan itu kita ikuti.

\section{Senyapan Pengulangan}

Peneliti memaparkan kembali tentang bentuk senyapan dalam tuturan Joko Widodo dalam acara Jokowi Dikepung Kritik di Kompas TV. Selain senyapan yang telah disampaikan di atas bentuk senyapan pengulangan ditemukan dalam produksi ujaran presiden. Pada pembahasan Undang-Undang Cipta Kerja berbagai rentetan pertanyaan disampaikan oleh Rosi sebagai pewawancara dalam acara tersebut. Pada segmen pertama ini Rosi meminta tanggapan presiden bahwa Undang-Undang Cipta Kerja banyak yang menolak dan dianggap sebagai Undang-Undang yang terburuk sepanjang sejarah. Dalam menanggapi hal tersebut presiden memberikan jawaban 
bahwa ini proses demokrasi di negara kita ada yang pro dan kontra dan hal itu biasa. Dalam menyampaikan tanggapannya tersebut ditemukan senyapan pengulangan di awal kalimat, yaitu inilah.ketika presiden memberikan tanggapan. Presiden mengulang kata inilah..inilah di awal kalimat sebelem presiden mepaparkan lebih lanjut tanggapannya. Selain itu senyapan pengulangan muncul kembali pada tuturan presiden dengan mengulan kata ada. Hal tersebut dapat dillihat pada data (7)

(7) ya inilah... inilah proses demokrasi di negara kita ada yang pro ada yang kontra, menurut saya ya biasa menanggapi sebuah kebijakan ada, ada yang pro ada yang kontra itu biasa kok dan e saya melihat banyak yang belum memahami juga banyak yang belum membaca isi dari omnimbuslaw ini. Ini segini lo bukunya (menunjukkan perkiraan ketebalan Undang- Undang Cipta Kerja).

Senyapan pengulangan kemudian ditemukan kembali ketika Rosi mempertanyakan apakah keberanian menteri-menteri saat ini sudah sesuai dengan harapan presiden. Menjawab pertanyaan tersebut presiden menjelaskan bahwa yang paling penting berani mengeksekusi kebijakan-kebijakan. Di awal tuturan dalam menyampaikan penjelasan senyapan pengulangan muncul hingga dua kali. Senyapan pengulangan pertama beupa mengulang kata tidak dan selang beberapa detik muncul senyapan pengulangan berupa kata harus. Hal tersebut dapat dilihat pada tuturan data (8).

(8) Berani itu tidak...tidak..ini ya tidak harus...harus..kelihatan apa sangar gitu ya, tapi yang paling penting berani itu berani mengeksekusi kebijakan-kebijakan yang emang sulit, keberanian itu yang kita butuhkan.

\section{Senyapan Pemanjangan}

Dalam tuturan Presiden Joko widodo ditemukan bentuk senyapan pemanjangan. Senyapan tersebut dapat dilihat pada penggalan tuturan presiden yang disajikan pada data (9).

(9) Ini memerlukan (diperpanjang) pemikiran, kita tidak hanya memikirkan yang sudah bekerja, tetapi yang tidak bekerja yang belum bekerja, dan yang akan bekerja ini seperti apa.

Berdasarkan data di atas senyapan perpanjangan muncul ketika presiden menuturkan kata memerlukan pada kalimat ini memerlukan pemikiran. Dalam tuturan tersebt presiden mencoba mengajak untuk berpikir tentang kondisi rakyat Indonesia di masa pandemi saaat ini.

Selanjutnya ditemukan kembali contoh senyapan pemanjangan dalam tuturan presiden. Senyapan tersebut ditandai dengan pemanjangan kata ya dan sudah yang disampaikan dengan intonasi panjang. Jika digambarkan tuturan tersebut yaaaa//ada yang sudahh//ada yang belum. Pemanjangan kata tersebut menunjukkan bahwa presiden sedang berpikir dalam memberikan jawaban atas pertanyaan Rosi tentang keberanian para menteri saat ini. Tuturan presiden yang mengandung senyapan terisi dapat dilihat pada data (10).

(10) ya (dipanjangkan) ada yang sudah (dipanjangkan) ada yang belum.

\section{Senyapan Kombinasi}

Peneliti pada uraian ini menyajikan contoh senyapan kombinasi dalam tuturan Presiden Joko Widodo dalam acara Jokowi Dikepung Kritik. Senyapan kombinasi pada tuturan presiden dapat dilihat pada data (11).

(11) ... Artinya lebih efektif di mini lockdown di wilayah-wilayah RT atau kelurahan atau RW, ya ini apa itu e... strategis-strategis sepertinya selalu berubah ...

Pada cuplikan contoh senyapan kombinasi pada tuturan Presiden Joko Widodo pada data 11 tampak kombinasi senyapan terisi berupa kalimat apa itu dan bunyi e.... Senyapan tersebut muncul saat Rosi menanyakan strategi yang digunakan dalam menangani wabah Covid-19 di Indonesia.

Di bawah ini peneliti menyajikan kembali senyapan kombinasi yang muncul pada tuturan Presiden Joko Widodo.

(12) Ya (dipanjangkan) e... yang pertama itu tidak ada satu negarapun yang bisa dijadikan model yang baik itu yang seperti apa karena ini baru. 
Pada data 12 tersebut presiden mencoba memberikan tanggapannya terkait wabah covid-19 di Indonesia. Dalam menyampaikan tuturannya ditemukan senyapan kombinasi berupa senyapan perpanjangan pada kata ya dan senyapa terisi berupa bunyi e. Senyapan kombinasi tersebut muncul di awal penuturan Presiden.

\section{Senyapan False Start}

Seseorang dalam menyampaikan tuturannya kadangkala mengalami gangguan sehingga menimbulkan kesenyapan. Hal tersebut juga terjadi padaseorang presiden. Senyapan yang dialami oleh Presiden Joko Widodo muncul ketika beliau memaparkan tanggapannya terkait UndangUndang yang tumpang tindih dan perlu revisi. Dalam penjelasan beliau ketika menggunakan kato harmonisasi diawali dengan menyebutkan harmonasa sehingga timbul senyapan untuk memperbaiki kata yang disampaikan oleh beliau. Hal tersebut dapat dilihat pada data (13) berikut.

(13) ... Pertama tadi harmonasa harmonisasi undang-undang yang tumpang tindih yang perlu direvisi, yang kedua memang kita ingin melakukan reformasi struktural dalam rangka reformasi ekonomi ...

Di bawah ini masih disajikan contoh senyapan false start yang muncul dalam tuturan presiden dalam wawancara. Kemunculan tuturan tersebut dipicu oleh pertanyaan Rosi tentang pelaksanaan Pilkada di masa pandemi. Dalam penjelasan presiden, muncul kata mensosialisasikan, namun dalam mengawali kata tersebut presiden mengucapkan mensosa. Presiden menyadari hal tersebut segera memperbaiki tuturannya dengan menuturkan mensosialisasikan. Selanjutnya masih dalam tuturan yang sama, muncul false start dalam tuturan presiden. Senyapan tersebut muncul ketika beliau hendak mengatakan kata dikerjakan, namun untuk menuturkan hal tersebut beliau mengawali dengan menuturkan di..di..hingga belaiu mampu mengatakan dengan benar, yaitu dikerjakan. Oleh karena itu dalam pengucapan yang salah tersebut terjadi senyapan. Tuturan presiden tersebut dapat dilihat pada data (14) berikut.

(14) saya sampaikan juga ke MENDAGRI, agar disampaikan ke calon-calon untuk justru ikut mensosa..sosialisakan, mengampanyekan mengenai protokol kesehatan. Mengenai pakai masker, mengenai cuci tangan, mengenai e... jaga jarak tidak berkerumun..tidak berkerumun. Saya kira kampanye itu yang justru sekarang ini yang dii...dii...dikerjakan oleh kandidatkandidat. Saya lihat itu berjalan.

\section{Senyapan Diam}

Kesenyapan dimaknai sebagai suatu jeda dalam tuturan yang memisahkan dengan tuturan selanjutnya. Kesenyapan muncul karena dipengaruhi oleh berbagai faktor. Hal tersebut juga dialami oleh Presiden Joko Widodo dalam menyampaikan tuturan-tuturannya dalam wawancara eksklusif di Kompas TV. Kesanyapan berupa senyapan diam muncul dalam tuturan presiden. Hal tersebut dapat dilihat pada penyajian data berikut.

(15) ... Nah kalau targetnya nggak ketemu, bekerjanya biasa-biasa saja, rutinitas ya sayall ya marah dongsaya marah.

(16) ... Jadi kita itu menyesuaikan dari pengalaman sebelumnya yang kita miliki//dari bulan pertama, bulan kedua, bulan ketiga selalu kita evaluasi ...

Pada data 15 senyapan diam muncul ketika presiden memaparkan penjelasannya terkait kemarahannya ketika para menteri tidak mencapai target yang telah ditetapkan. Dalam data 15 tampak ketika presiden mengatakan ya saya, kemudian diam sejenak untuk mengatakan kalimat berikutnya, yaitu ya marah dong saya marah. Senyapan tersebut terletak ditengah setelah frasa nomina, yaitu saya. Kemudian pada data 16 juga menunjukkan senyapan diam yang terletak ditengah setelah frasa nomina, yaitu kita. Setelah mengatakan kita presiden menuturkan kata miliki dan kemudian terjeda. Senyapan yang dilakukan presiden pada kata miliki menunjukkan presiden sedang berpikir untuk memilih kata yang tepat untuk tuturan berikutnya.

Di bawah ini juga merupakan senyapan diam yang muncul dalam tuturan presiden. Senyapan tersebut muncul ketika presiden menjelaskan tentang vaksin untuk mencegah covid 
19. Senyapan tersebut terletak di tengah tuturan presiden, yaitu setelah beliau menuturkan sehingga penting yang namanya (diam sejenak), kemudian beliau tampak berpikir untuk memilih tuturannya selanjutnya yang tepat, yaitu beliau menuturkan emergency use auto reaseation. Untuk kelengkapan tuturan presiden dapat dilihat pada data (17) berikut ini.

(17) Harus melalui kaidah-kaidan saintic, sehingga penting yang Namanya // emergency use auto reaseation yang nanti akan dikeluarkan oleh BPOM

\section{Penyebab Senyapan dalam Tuturan Presiden Joko Widodo dalam Wawancara Eksklusif di Kompas TV}

Dari hasil penelitian ditemukan beberapa alasan terjadinya senyapan pada tuturan Presiden Joko Widodo dalam wawancara eksklusif di Kompas TV yakni sebagai berikut.

\section{Lupa Akan Kata-Kata yang Diperlukan}

Senyapan juga disebabkan karena lupa akan kata-kata yang diperlukan. Presiden menggunakan kata apa yang menandakan bahwa beliau lupa dan berusaha untuk mengingat kata yang selanjutnya akan diucapkan.

Seperti yang tampak pada kutipan data berikut ini.

(1) Iya, iya perlu didengar iya, tapi apa ini undang-undang ini disiapkan dalam jangka yang sudah lama. Kemudian dibahas di DPR seingat saya delapan bulan dan juga sebuah proses yang lama di situ ada pro dan kontra, ada proses-proses apa demokrasi di sana. saya kira apa e... proses-proses itu juga harus kita hargai, tetapi bahwa ada apa hal-hal yang masih belum baik, masukan-masukan yang perlu kita akomodir saya kira itu sesuatu yang baik. Jadi e... ini adalah apa e... harmonisasi dari banyak undang-undang yang direvisi. Ada tujuh puluh sembilan undang-undang yang direvisi di sini, ini juga untuk harmonisasi undang-undang yang tumpang tindih dan ini juga untuk reformasi struktural dalam rangka transformasi ekonomi. ....

(2) Ya kalau apa diajak berbicara tidak mau ya gimana kita jugakan sulit ya. Kitakan nggak bisa menangkap apa yang di e...dimaui, tapi ini sekali lagi pemerintah akan tetap mengajak terutama pembuatan PP dan perpes, sehingga terakomodir keinginan-keinginan yang masih belum masuk di dalam undang-undang ini.

\section{Kehati-Hatian Memilih Kata}

Setiap orang tentunya berhati-hati ketika berbicara. Apalagi jika seseorang tersebut adalah seorang presiden atau politisi yang seringkali menjadi sorotan publik. Seperti pada kutipan di bawah ini, presiden juga sangat berhati-hati saat ditanya tentang anak dan menantunya yang mengikuti pilkada. Kehati-hatian tersebut menyebabkan senyapan pada tuturan beliau untuk berpikir agar tidak salah ucap. Hal itu ada dalam kutipan di bawah ini.

(3) Iya, saya tidak pernah memaksakan ya kepada anak-anak saya untuk mengikuti saya atau untuk masuk ke terjun ke dunia politik. Ndak..ndak..ndak ada, itu hak politis setiap warga negara memiliki hak politis termasuk anak-anak saya., memiliki hak politis (diam sejenak) sehingga waktu e...menyampaikan keinginan itu ya sudah, sudah kamu hitung sudah kamu kalkulasi, sudah pak.

(4) Ndak, jadi selama ada pilkada di Solo ( diam sejenak), saya pulang sekali dan itu malam, saya hanya nyekar saja ke orang tua, kemudian malam itu juga saya kembali lagi dan nginepnya di Yogya tidak di Solo.

\section{Ketidaksiapan Memulai Tuturan}

Ketika menjawab sebuah pertanyaan kadang kala seseorang belum siap untuk menjawab sehingga harus mengalami kesenyapan untuk memproduksi ujaran. Kesenyapan yang terjadi adalah diam sejenak. Seperti pada kutipan data di bawah ini.

(5) Iya ... e... kalau kita melihat ya memang (diam sejenak) apa (diam sejenak) semua pilihanpilihan itu tidak baik, pilihan-pilihan yang tidak baik. Jadi e... sehingga kita menekankanya diperketatnya protokol kesehatan, dicek di lokasi-lokasi wisata, ya e... arahnya ke sana karena 
kalau ini sudah kita putuskan inikan sebetulnya kompensasi dilibur idhul fitri yang lalu diseparo diberikan yang kemarin dan separonya diberikan lagi yang di akhir tahun ...

Presiden menjawab dengan diikuti senyapan berupa pengulangan pada saat beliau ditanya tentang keberanian menteri-menteri pada periode kedua ini, sehingga belum ada penggantian menterimenteri atau reshuffle kabinet sampai saat ini yang tidak seperti pada periode pertama. Hal ini disebabkan karena beliau sudah terlanjur memulai ujaran, tetapi sebenarnya belum siap untuk seluruh kalimat itu. Hal itu tampak pada kutipan data di bawah ini.

(6) Ya... ada yang sudah ada yang belum. Berani itu tidak...tidak...ini ya tidak harus...harus..kelihatan apa sangar gitu ya, tapi yang paling penting berani itu berani mengeksekusi kebijakan-kebijakan yang emang sulit, keberanian itu yang kita butuhkan.

\section{Adanya Kekeliruan Tuturan}

Kesenyapan juga bisa terjadi disebabkan oleh adanya kekeliruan tuturan. Seperti pada kutipan data di bawah ini. Ketika presiden sudah terlanjur mengatakan pak padahal bukan kata itu yang dibutuhkan kemudian tuturan tersebut mengalami senyapan terisi $e \ldots$ untuk berpikir melanjutkan tuturan yang keliru tadi.

(7) Iya ...iya ... kemudian juga e... sudah bertemu setelah e... proses omnimbuslaw ini dengan e... NU sudah, dengan muhammadiyah sudah, dengan MUI sudah, dan saya mengucapkan terima kasih, banyak masukan-masukan dari beliau-beliau kepada kita, saya pak e... nanti bisa kita pakai sekali lagi dalam PP maupun Perpres dan ada kesamaan mengenai pemberdayaan UMKM, mengenai pembenahan ekonomi umat.

\section{Pengubahan Isi Tuturan}

Selain senyapan yang terjadi karena kekeliruan, ada pula penyebab senyapan yang bertujuan mengubah isi tuturan yakni mengubah tuturan sebelumnya yang salah tadi, seperti kutipan di bawah ini.

(8) .... Artinya lebih efektif di mini lockdown di wilayah-wilayah $R T$ atau kelurahan atau RW, ya ini apa itu e... strategis-strategis sepertinya selalu berubah, sehingga saat itu waktu itu ada sembilan e... delapan provinsi e... kasusnya naik, ya sama. Kitakan punya 34 Provinsi tapi yang sembilan e... yang delapan ini naik, sehingga saya perintah saat itu bukan mengganti ya, perintah agar yang delapan provinsi ini diurus oleh Pak Luhud. Menkomarifes yang memang di dalam e... komite beliau ini wakil ketua, urus yang delapan yang lain biar diurus oleh organisasi yang biasa.

Pada kutipan di atas presiden sudah terlanjur mengatakan pernyataan yang keliru yakni tentang provinsi yang kasusnya naik. Sebelumnya beliau menyebut ada sembilan provinsi, kemudian terjadi senyapan terisi $e \ldots$ untuk berpikir sejenak dan melanjutkan dengan memperbaiki pernyataan yang keliru tadi.

Begitu juga pada kutipan data di bawah ini. Beliau juga keliru menyebutkan pernyataan sebelumnya yang mengatakan ada seribu seratus diperbaiki menjadi seribu dua ratus saat menyebutkan jumlah pasal, yakni sebagai berikut.

(9) Seribu serat e... seribu dua ratus empat puluh empat pasal itu juga tidak sedikit. Ada sebelas kluster di sini yang macam-macam, sehingga ini memerlukan ahli hukum yang tidak sektoral tetapi yang banyak sekali sektornya, ini yang e... apa yang tidak dibayangkan sebelumnya sehingga kalau ada hal yang kurang iya itu yang diperbaiki. ....

\section{Ragu-Ragu Karena Mengingat-Ingat Kejadian di Masa Lampau}

Data berikut ini menunjukkan senyapan pengulangan yang terjadi disebabkan oleh rasa raguragu untuk mengucapkan hal tersebut karena masih mengingat-ingat tentang perkembangan ekonomi jika dibandingkan dengan masa sebelumnya yang tampak pada kutipan data di bawah ini.

(10) Ya kalau dari angka-angka dari angka-angka memang di kwartal ketiga ini tumbuh ekonomi kita minus 3,49 dari yang sebelumnya kwartal kedua 2,32 minus. 
Artinya lebih baik, angka minus 3,49 itu didukung oleh konsumsi pemerintah yang tinggi meningkat, dari yang minus 6 ke plus 9.6 koma menjadi plus 9 koma, inikan artinya apa tinggi sekali lo loncatannya yang lain-lain minus.

(11) Iyaa harus disampaikan, ada beberapa kementerian yang memang masih belum. Ya saya sampaikan lagi, saya ulang tu, tapi artinya di akhir September sudah muncul angka sembilan plus angka e... plus sembilan koma tadi. Artinya ada perbaikan yang sangat signifikan.

\section{Mencari Kata-Kata yang Tepat untuk Disampaikan}

Pada kutipan di bawah ini peneliti menemukan senyapan pengulangan yakni inilah... inilah dan $a d a \ldots$ ada serta senyapan terisi $e . .$. yang terjadi disebabkan oleh adanya proses berpikir untuk mencari kata-kata yang tepat untuk disampaikan, yakni sebagai berikut.

(12) Ya inilah... inilah proses demokrasi di negara kita ada yang pro ada yang kontra, menurut saya ya.... biasa menanggapi sebuah kebijakan ada... ada yang pro ada yang kontra itu biasa kok dan e... saya melihat banyak yang belum memahami juga banyak yang belum mem..baca isi dari omnimbuslaw ini. Ini segini lo bukunya, jadi e...kalau sudah membaca, menurut saya mereka akan...mereka akan berubah.

Pada kutipan di bawah ini peneliti menemukan senyapan terisi anu yang terjadi juga disebabkan oleh adanya proses berpikir untuk mencari kata-kata yang tepat untuk disampaikan, yakni sebagai berikut.

(13) (Tertawa), ini jadi yang paling penting ini anunya dulu, yang paling penting satu kita harus hati-hati terhadap yang namanya vaksin ini.

(14) Kita sudah punya list kok, listnya apa e... siapa-siapa yang disuntik dan di lokasi mana. Nanti minggu depan, insyaalah kita sudah mulai simulasi, minggu depan.

Pada kutipan di bawah ini peneliti menemukan senyapan perpanjangan $Y a \ldots$ yang terjadi juga disebabkan oleh adanya proses berpikir untuk mencari kata-kata yang tepat untuk disampaikan, yakni sebagai berikut.

(15) Ya... ada yang sudah ada yang belum. Berani itu tidak...tidak..ini ya tidak harus...harus..kelihatan apa sangar gitu ya, tapi yang paling penting berani itu berani mengeksekusi kebijakan-kebijakan yang emang sulit, keberanian itu yang kita butuhkan.

\section{Pembahasan}

Dalam menyampaikan tuturan seseorang selalu ingin menyampaikan dengan sempurna tanpa ada kendala, namun pada kenyataannya hal tersebut tidaklah mungkin. Dalam menyampaikan tuturan seseorang baik secara sadar maupun tidak sadar akan mengalami gangguan, salah satunya berupan senyapan. Terkait hal tersebut dalam penelitian ini ditemukan bentuk senyapan dalam tuturan Presiden Joko Widodo. Senyapan yang ditemukan meliputi senyapan terisi berupa bunyi, senyapan terisi berupa kata, senyapan pengulangan, senyapan pemanjangan, senyapan kombinasi, senyapan false start, dan senyapan diam. Penelitian serupa pernah dilakukan dan menunjukkan beberapa bentuk senyapan yang sama dengan yang dilakukan oleh peneliti, yaitu berupa senyapan terisi dengan pengisi berupa bunyi dan kata, pengulangan, pemanjangan, kombinasi, pengulangan, false start, dan senyapan diam[10].

Blocking atau senyapan muncul karena adanya keraguan ketika penutur akan mengujarkan sesuatu pernyataan. Hal tersebut dibuktikan melalui penelitian ini, misalnya pada senyapan berupa bunyi e, pengulangan progresif berupa pengulangan pada kata ini, menjadi inilah ... inilah, dari kata tidak diulang menjadi tidak.tidak.Munculnya senyapan pengulangan pada tuturan presiden sebagai upaya di saat presiden memikirkan jawaban yang tepat. Pengulangan yang dilakukan presiden dalam tuturannya tidak dapat disamakan dengan proses reduplikasi, seperti pada lari-lari atau makanmakan. Akan tetapi pengulangan yang dilakukan oleh presiden sebagai bentuk proses berpikir yang menyebabkan kesenyapan dan menekankan suatu hal yang dianggap penting. 
Dardjojowidjojo mengatakan bahwa ada berbagai alasan mengapa orang senyap. Pertama orang senyap karena dia telah terlanjur memulai dengan ujarannya, tetapi ia sebenarnya belum siap untuk seluruh kalimat itu. Karena itu dia senyap sejena untuk mencari kata atau kata- kata untuk melanjutkan ujarannya. Kedua bisa juga kesenyapan ini terjadi karena ia lupa akan katakata yang ia perlukan karena itu ia harus mencarinya untuk melanjutkan ujarannya. Kemungkinan ketiga adalah bahwa dia harus sangat berhati-hati dalam memilih kata agar dampaknya pada pendengar atau publik tidak misalnya menghebohkan. Tipe ketiga ini umumnya terjadi pada pejabat publik atau kaum politikus yang harus berhati-hati memilih kata- katanya[11].

Sesuai dengan pendapat Dardjojowidjojo di atas peneliti juga menemukan alasan penyebab senyapan meliputi tiga hal tersebut yakni (1) terlanjur memulai dengan ujarannya, tetapi ia sebenarnya belum siap untuk seluruh kalimat itu, (2) lupa akan kata-kata yang ia perlukan karena itu ia harus mencarinya untuk melanjutkan ujarannya, (3) berhati-hati dalam memilih kata agar dampaknya pada pendengar atau publik tidak misalnya menghebohkan.

Senyapan juga bisa terjadi karena kekeliruan. Kurniawati mengemukakan bahwa tidak dapat dipungkiri bahwa ketika bertutur, kekeliruan dapat saja terjadi. Contoh yang paling umum ialah kekeliruan berupa keseleo lidah. Keseleo lidah merupakan kekeliruan tutur karena penutur mengucapkan satuan lingual tertentu dengan tidak seperti yang direncanakan atau dimaksudkannya[6].

Kekeliruan tuturan yang disebutkan oleh Kurniawati tersebut juga menyebabkan kesenyapan. Setelah melakukan keselo lidah, penutur dapat saja kemudian senyap untuk memperbaiki tuturan tersebut. Pada data juga ditemukan penyebab senyap karena kekeliruan tuturan.

Blend atau campur kata merupakan kekeliruan tuturan berupa penggabungan dua kata yang berdekatan. Kekeliruan ini umumnya terjadi saat penutur tergesa-gesa atau tidak berkonsentrasi. Dari sudut pandang kilir lidah, senyapan dimanfaatkan sebagai cara untuk mengulur waktu sampai kata yang tepat sebagai bentuk koreksi ditemukan. Adapun dari sudut pandang senyapan, kilir lidah merupakan penyebab hadirnya senyapan dalam tuturan. Data penelitian menunjukkan bahwa blend diikuti senyapan berupa senyapan terisi[1].

Karena penutur mengucapkan tuturannya sambil merencakan tuturan tersebut, dapat saja dalam phonological encoding ia kemudian mengubah isi tuturan. Atau dapat saja orang senyap karena ia telah terlanjur memulai dengan ujarannya, tetapi sebenarnya belum siap untuk keseluruhan tuturan. Alasan senyap karena mengubah isi tuturan ini berbeda dengan alasan senyap karena telah melakukan kekeliruan. Agak sulit membedakan keduanya. Namun, hal itu setidaknya dapat dilihat dari hubungan yang ada[6].

Penutur juga dapat mengalami senyap karena alasan belum sepenuhnya siap untuk menyampaikan tuturan yang akan diucapkannya. Oliveira dalam Kurniawati menyampaikan bahwa senyapan ini biasanya berupa senyapan panjang yang terjadi karena penutur sedang memformulasi gagasan. Dalam acara debat ini ada sesi yang meminta pasangan calon memberikan tanggapan atas pertanyaan atau pernyataan moderator dan pasangan lain yang bersifat tidak terduga, bahkan "sedikit menyerang" pendapat atau tindakan sebelumnya dari pasangan calon. Oleh sebab itu, senyapan karena alasan ini tidaklah jarang dijumpai. Dalam hal ini penutur menyiapkan tuturannya sambil memulai bertutur[6]. Senyapan keraguan tidak terdapat di sembarang tempat. Akan tetapi, di mana persisnya belum ada kesepakatan yang mantap di antara para ahli. Ada yang mengatakan bahwa senyapan seperti itu terdapat terutama sesudah kata pertama dalam suatu klausa atau kalimat, tetapi ada pula yang mengatakan bahwa senyapan terdapat terutama sebelum bentuk leksikal yang penting[5].

Kesenyapan juga terjadi karena keraguan. Dimana kesenyapan dan keraguan dalam ujaran terjadi karena pembicara lupa kata-kata apa yang dia perlukan, atau dia sedang mencari kata yang paling tepat, dan sebagainya. Kesalahan yang berupa kilir lidah menunjukkan bahwa kata ternyata tidak tersimpan secara utuh dan orang harus meramunya[5]. 


\section{SIMPULAN}

Dari paparan data di atas dapat disimpulkan bentuk senyapan pada tuturan Presiden Joko Widododalam wawancara eksklusif di Kompas TV meliputi senyapan terisi berupa bunyi, senyapan terisi berupa kata, senyapan pengulangan, senyapan pemanjangan, senyapan kombinasi, senyapan false start, dan senyapan diam. Kemudian penyebab senyapan yang terjadi yakni terlanjur memulaiujaran, tetapi sebenarnya belum siap untuk seluruh kalimat itu, lupa akan katakata yang diperlukan, kehati-hatian memilih kata, ketidaksiapan memulai tuturan, adanya kekeliruan tuturan, pengubahan isi tuturan, ragu-ragu karena mengingat-ingat kejadian di masa lampau, mencari kata-kata yang tepat untuk disampaikan. Penelitian ini dapat memberikan konstribusi pada pembelajaran keterampilan berbicara dan menambah informasi pada kajian bidang psikolinguistik. Peneliti berharap akan ada tindak lanjut kajian bidang Psikolinguistik tentang proses mental dalam memproduksi ujaran

\section{REFERENCES}

[1] F. Pangesti, "Senyapan dan kilir lidah berdampingan dalam produksi ujaran," Hast. Wiyata, vol. 2, no. 1, pp. 1-10, 2019, doi: 10.21776/ub.hastawiyata.2018.002.01.02.

[2] R. Dufour, V. Jousse, Y. Estève, F. Béchet, and G. Linarès, "Spontaneous speech characterization and detection in large audio database," SPECOM'2009, St.Petersburg, 21-25 June 2009, vol. 1, no. June, pp. 41-46, 2009.

[3] S. Hidayatullah and M. Y. Romadhon, "Analisis Peristiwa Tutur (Speaking) Dalam Acara Ngobras Bersama Dekan Fkip Umus Brebes," J. Ilm. Semant., vol. 2, no. 01, pp. 1-12, 2020, doi: 10.46772/semantika.v2i01.258.

[4] I. Mayasari, "SENYAPAN DAN KILIR LIDAH DALAM PRODUKSI UJARAN (KAJIAN PSIKOLINGUISTIK)," DEIKSIS, vol. 7, no. 2, 2015, doi: http://dx.doi.org/10.30998/deiksis.v7i02.543.

[5] D. L. Rahmawati, "Senyapan Pada Ujaran Iwan Fals di Acara Talkshow Kick Andy "Akhirnya Iwan Fals Bicara,"” Anterior J., vol. 14, no. 1, pp. 71-80, 2014.

[6] W. Kurniawati, "Senyapan Dalam Tuturan Berbahasa Indonesia: Studi Terhadap Tuturan Pada 'Debat Pilkada DKI 2017,"” J. Ilm. Kebahasaan dan Kesastraan WIDYAPARWA, vol. 46, no. 1, pp. 75-90, 2018, doi: https://doi.org/10.26499/wdprw.v46i1.165.

[7] P. J. M. Pertiwi, Patriantoro, and A. Syahrani, "Senyapan dan selip lidah terhadap produksi ujaran dalam sidang ke-14 jessica kumala wongso," J. Pendidik. dan Pembelajaran Khatulistiwa, vol. 7, no. 3, pp. 1-10, 2018.

[8] N. Sasmitasari and S. Saman, "Senyapan dan Penyebabnya Pada Debat Final Pemilihan Kepala Daerah Khusus Ibukota Jakarta Tahun 2017," J. Pendidik. dan Pembelajaran Khatulistiwa, vol. 8, no. 1, pp. 1-13, 2019.

[9] G. E. G. Lombogia, "Senyapan di Dalam Gelar Wicara The Tonighy Show Starring Jimmy Fallon Suatu Analisis Psikolinguistik," J. Elektron. Fak. Sastra Univ. Sam Ratulangi, vol. 13, 2020, [Online]. Available: https://www.nbc.com/the-tonight-show.

[10] A. Manshur and F. Z. I, "Senyapan dan Kilir Lidah Dalam Acara Gelar Wicara Mata Najwa 2020 Sebagai Kajian Psikolinguistik,” J. PENEROKA, vol. I, no. 1, pp. 24-41, 2021.

[11] S. Dardjowidjojo, Psikolinguistik: Pengantar Pemahaman Bahasa. 2003. 